\title{
Determination of Lead(II) in Liver Corpse of a Slaughtered Cattle with Preconcentration on a Chelating Sorbent
}

\author{
R. A. Aliyeva1, N. S. Huseynova ${ }^{2}$, Ulviya M. Abilova1 ${ }^{*}$, G. B. İskandarov², F. M. Chiragov ${ }^{1}$ \\ ${ }^{1}$ Department of Analytical Chemistry, Faculty of Chemistry, Baku State University, Baku, Azerbaijan \\ ${ }^{2}$ Department of the General and Toxicological Chemistry, Faculty of Pharmacology, Azerbaijan Medical \\ University, Baku, Azerbaijan \\ Email: *u.abilova@mail.ru
}

Received 19 February 2016; accepted 5 August 2016; published 8 August 2016

Copyright (C) 2016 by authors and Scientific Research Publishing Inc.

This work is licensed under the Creative Commons Attribution International License (CC BY).

http://creativecommons.org/licenses/by/4.0/

(c) (i) Open Access

\section{Abstract}

The copolymer of the maleic anhydride-styrene is modified at the presence of 4-amino-2-thiouracil and formaldehyde and the new polymeric sorbate with spatial structure is received. The received sorbate is identified by the IR-spectroscopy method. The complete static sorption capacitance was studied $\left(\mathrm{CSSC}_{\mathrm{K}}^{+}=7.8 \mathrm{mmol} / \mathrm{g}\right)$ and the ionization constants of ionic groups in a sorbate link was defined by electrometric method. Ionization constants were determined by potentiometric titration of the sorbent $\left(\overline{\mathrm{pK}}_{1 \text { (calc) }}=3.87, \mathrm{pK}_{1 \text { (graph.) }}=4.00, \overline{\mathrm{pK}}_{2(\text { (alc) })}=8.31, \mathrm{pK}_{2(\text { graph) }}=8.40\right)$. Sorption and desorption of the received sorbent with a lead ion (II) are investigated and optimum concentration conditions are defined: $\mathrm{pH}_{\mathrm{opt} .}=5$, ionic force $\mu=0.8 \mathrm{pier} / \mathrm{l}$, full sorption balance 4 hours, optimum eluent $5 \mathrm{ml}$ of $0.5 \mathrm{M} \mathrm{HCl}$.

\section{Keywords}

Sorption Capacity, Preconcentration, Polymeric Sorbate, Lead(II)

\section{Introduction}

Slight lead content in animal and human organs necessitates its selection and concentration before subsequent determination. The intense way of restoring the amino acids necessary for proper formation and tissue growth is possible only with consumption of animal protein. Animal protein sources in Azerbaijan are beef, poultry and

*Corresponding author.

How to cite this paper: Aliyeva, R.A., Huseynova, N.S., Abilova, U.M., İskandarov, G.B. and Chiragov, F.M. (2016) Determination of Lead(II) in Liver Corpse of a Slaughtered Cattle with Preconcentration on a Chelating Sorbent. American Journal of Analytical Chemistry, 7, 617-622. http://dx.doi.org/10.4236/ajac.2016.78057 
lamb. Messy dumping on land and in water of bodies, illegal extraction of ore and painting houses, the use of tetra ethyl lead as an anti-knock additive to improve asoline quality in Azerbaijan and in many other developing countries leads to lead poisoning animals. Cattle and other ruminants graze freely in these conditions, and drink water from ponds, streams, rivers and other possible sources of pollution, which are hazardous to human and animal health. These metals bio-accumulate in the organs and other tissues of these animals. When these animals are killed for human consumption, lead can bio-accumulate in human tissues and organs. This explains why the lead level in animal products continues to be the center of attention of health workers [1]-[5]. Lead can negatively affect many organs and life-support systems, causing high blood pressure, anemia, kidney damage, hearing loss and mental retardation [6]. This research was conducted to determine the level of lead residue in the cattle's liver in Baku. In case of determination of small amounts of metals in various sites, preconcentration is often necessary.

These include methods of using of sorptive chelate adsorbents. Their high selectivity allows you to retrieve hard metals from solutions of complex composition [7]. Determination of trace amounts of lead in the environment is possible only after pre-concentration. To increase the selectivity and effectiveness of lead concentration azo containing sulfur, sorbents are often used and have high practical interest in determining its complex objects in [8]. Chelating properties of selective sorbents caused by the presence of complexing groups depend on the experimental conditions of $\mathrm{pH}$, saline background and the presence of the masking agents. Previously, it was shown that chelate sorbent-copolymer of maleic anhydride with styrene, modified with ternary amines in the presence of formaldehyde, effectively absorbed acidic and alkaline environment ions of $\mathrm{Cu}, \mathrm{Fe}, \mathrm{Cd}, \mathrm{U}, \mathrm{Zn}$ and other elements [9].

The main objective in the present study is to investigate the sorption and desorption of $\mathrm{Pb}(\mathrm{II})$ obtained by the sorbent and to determine the optimal concentration condition.

The sorption capacity of sorbent to the amount of lead is $-497 \mathrm{mg} / \mathrm{g}(2.40 \mathrm{mmol} / \mathrm{g})$. This indicator is not inferior in such well-known complexing sorbents as PSTM-3T (CE = $160 \mathrm{mg} / \mathrm{g})$, fibrous sorbents with nitrogen-containing functional groups, the Academy of Sciences 1 (1.33 mmol/g) AL-1 (0.43 mmol/g), KH-1 (0.21 mmol/g), AN-3 (0.035 mmol/g) [6]-[8]. Potentiometric method defined ionization constants of ionic groups in a part of the sorbent. The methodology was used for the sorption-photometric determination of lead in the liver of cattle.

\section{Experimental Section}

\subsection{Reagents and Apparatus}

All the chemicals and reagents used in this work are of analytical grade and standart solution of lead(II) ion was prepared by dissolving $\mathrm{Pb}\left(\mathrm{CH}_{3} \mathrm{COO}\right)_{2}$ in water. Lead(2+) solution with concentration $1.0 \times 10^{-2} \mathrm{mg}^{-1} \cdot \mathrm{l}^{-1}$ is used in this work. The calculated amount of $\mathrm{KCl}$ was introduced to maintain a constant ionic strength. Caustic potassium hydroxide used for potentiometric titration of solutions was prepared by dissolving $\mathrm{KOH}$ (c.p.) in distilled water, the concentration of solution was determined by titration with standard solution of $\mathrm{HCl}$. The necessary $\mathrm{pH}$ values were created by using fiksanal $\mathrm{HCl}(\mathrm{pH} 1$ - 2) and ammonium acetate buffer solution (pH 3 - 11). $\mathrm{pH}$ of solutions were measured by ionomer I-130 with glass electrode. Optical density of solutions were measured by using of photocolorimeter KFK-2 $(\mathrm{l}=1 \mathrm{sm})$. For photometric determination of lead, we used xylene orange as a reagent. Concentration of $\mathrm{Pb}(\mathrm{II})$ was calculated by using of calibration curve and the results were worked up by math statistic methods [10]. The investigation of sorption was made in static conditions.

\subsection{The Method of Preparation of Chelating Polymer}

In this work, we applied a new polymer chelateforming sorbent with fragments of 4-amino-2-thiouracil. Radical copolymerization of maleic anhydride with styrene was carried out by the technique [11] [12]. Counted quantity of formalin and 4-amino-2-thiourasil is added to the received copolymer. The sorbents was synthesized by adding suitable amine and formaldehyde onto gotten copolymer. Reaction was performed on sand bath with continuously mixing. The reaction was performed in water medium. Therefore, copolymer's anhydride groups were hydrolyzed. Reaction lasts 30 - 40 min. under 333.15 - $343.15 \mathrm{~K}$ of temperature for removal of remaining parts of reaction product sorbent has been rinsed several times with distilled water. Then constant mass was dried in vacuum desiccators at $323 \mathrm{~K}$ and skipped through sieve with $0.14 \mathrm{~mm}$ of pore diameter. The synthesis reactions are shown below. 


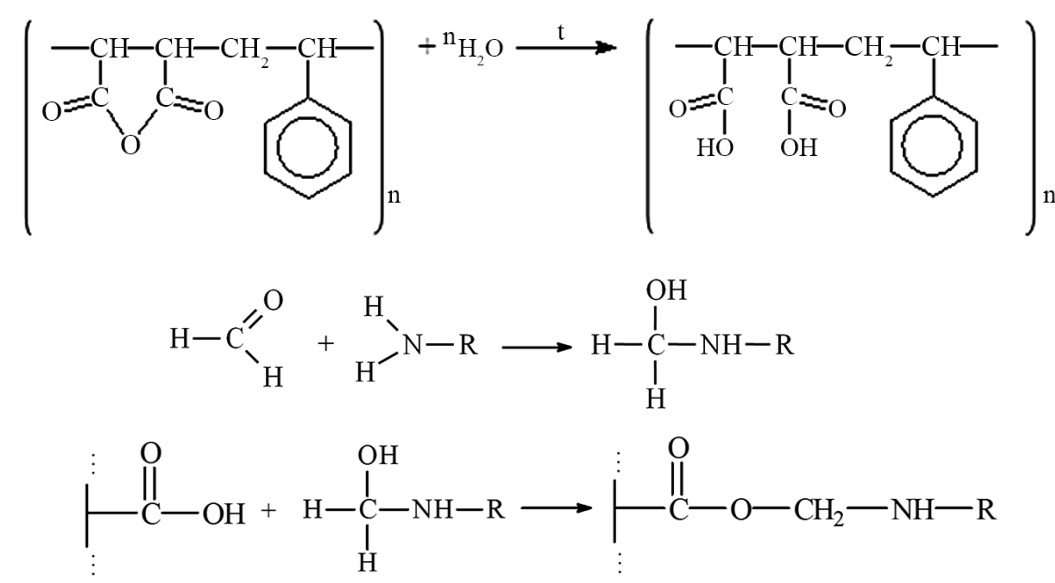

The resulting product was investigated by IR-spectroscopy.

\section{Results and Discussion}

\subsection{Absorption Spectra}

It is known that sorption properties of the sorbent depend on the dissociation constants of ionogenic groups contained in their composition. To study the acid-base properties of produced sorbent by a known method the complete static sorption capacitance was studied $\left(\mathrm{CSSC}_{\mathrm{K}}^{+}=7.8 \mathrm{mmol} / \mathrm{g}\right.$ ) and then verified by potentiometric titration [13]. Based on the results neutralization degree $(\alpha)$ of individual acidic groups and the magnitude of lg $\alpha / 1-\alpha$ were calculated as a function of $\mathrm{pH}$ for the construction of the potentiometric curve, which is characterized by two inflection points. From these data, using the modified equation Ganderson-Gasselbakh dissociation constants of alkaline groups $\mathrm{NH}_{2}^{+}$and detachment of protons from non-reactive carboxyl groups [14] [15]. Ioniza-

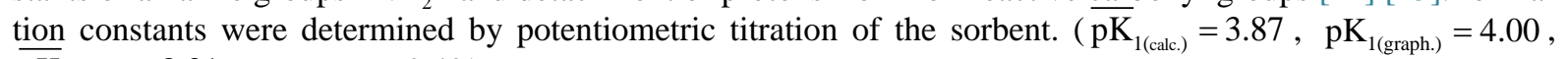
$\overline{\mathrm{pK}}_{2 \text { (calc.) }}=8.31, \mathrm{pK}_{2 \text { (graph) }}=8.40$ ).

$$
\mathrm{pK}_{\alpha}=\mathrm{pH}-\mathrm{nlg} \alpha / 1-\alpha
$$

We can see that the sorbent contains 2 different ionogenic groups. So the ionization of the sorbent goes on in 2 stages:

$$
\begin{aligned}
& \mathrm{H}_{2} \mathrm{R} \Leftrightarrow \mathrm{HR}^{-}+\mathrm{H}^{+} \\
& \mathrm{HR}^{-} \Leftrightarrow \mathrm{R}^{2-}+\mathrm{H}^{+}
\end{aligned}
$$

\subsection{Effect of $\mathrm{pH}$}

The effect of $\mathrm{pH}$ on the preconcentration of $\mathrm{Pb}(\mathrm{II})$ ions in static conditions, on chelating sorbents is in the $\mathrm{pH}$ range of 1 - 8. The influence of $\mathrm{pH}$ is shown in Figure 1. As can be seen, quantitative recovery of metal ions is achieved in the $\mathrm{pH}$ range of $4-6$.

For small values ( $\mathrm{pH} 1$ - 4) of the liquid phase low degree of recovery may be associated with protonation of functional groups in the sorbent phase and with a low swelling degree of the polymer. For these values of $\mathrm{pH}$ $\mathrm{Pb}$ (II) ions are in the form of $\mathrm{Pb}^{2+}$ [16]. With increasing of $\mathrm{pH}$ of the liquid phase (pH 5 - 6) the swelling degree of polymer sorbents increases [16].

\subsection{Effect of Initial Concentration of $\mathrm{Pb}^{2+}$ Ions on Sorbent's Sorption Capacity}

The effect of initial $\mathrm{Pb}(\mathrm{II})$ ions concentration on adsorption was studied at the range of $0.2 \times 10^{-3} \mathrm{~mol} \cdot \mathrm{l}^{-1}$ to $8.0 \times$ $10^{-3} \mathrm{~mol} \cdot \mathrm{l}^{-1}$. The percentage removal of $\mathrm{Pb}^{2+}$ ions increased with increasing of $\mathrm{Pb}^{2+}$ concentration. Investigation has shown that the maximum adsorption is observed when the metal ion concentration is $8.0 \times 10^{-3} \mathrm{~mol} \cdot \mathrm{l}^{-1}$. Results are illustrated on the diagram and table below (Table 1, Figure 2). 


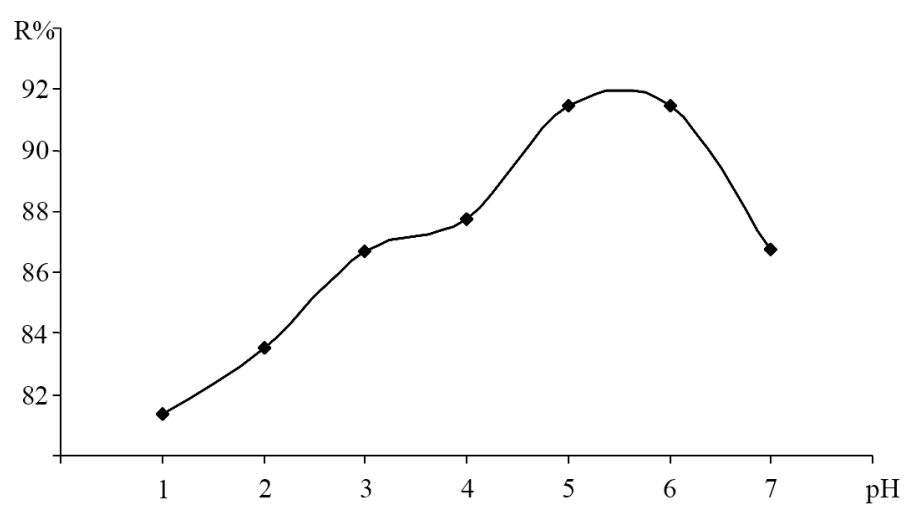

Figure 1. Effect of $\mathrm{pH}$ on recovery degree (R, \%) of $\mathrm{Pb}(\mathrm{II})$ ions (concentration of $\mathrm{Pb}$ (II) $200 \mathrm{mg} / \mathrm{l}$, solution volume $20 \mathrm{ml}, \mathrm{m}_{\text {sorp. }}=100$ $\mathrm{mg})$.

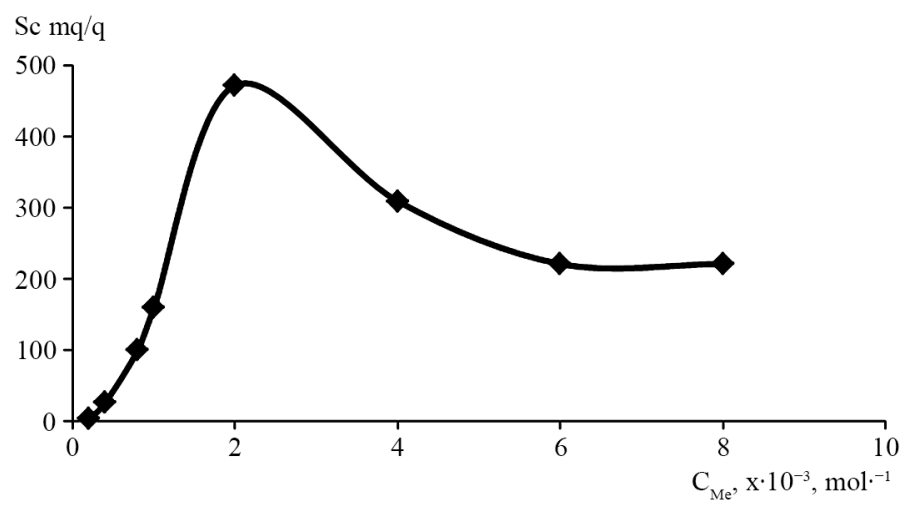

Figure 2. Effect of $\mathrm{Pb}^{2+}$ ions concentration on sorption capacity $\mathrm{m}_{\text {sorb. }}=$ $30 \mathrm{mg}, \mathrm{V}_{\text {total }}=20 \mathrm{ml}, \mathrm{C}_{\mathrm{Pb}^{2+}}=10^{-2} \mathrm{~mol} \cdot \mathrm{l}^{-1}$, time $120 \mathrm{~min}$., $\mathrm{pH}=5$.

Table 1. Removal efficiency percentage of $\mathrm{Pb}(\mathrm{II})$ ions by the investigated sorbent.

\begin{tabular}{ccccccccc}
\hline $\mathrm{C}_{\mathrm{Me}}, \times 10^{-3}, \mathrm{~mol} \cdot \mathrm{l}^{-1}$ & 0.2 & 0.4 & 0.8 & 1.0 & 2.0 & 4.0 & 6.0 & 8.0 \\
$\mathrm{~S}_{\mathrm{c}}, \mathrm{mq} / \mathrm{q}$ & 3 & 26 & 100 & 160 & 472 & 309 & 221 & 221 \\
\hline
\end{tabular}

$\mathrm{S}_{\mathrm{c}}-$ sorption capacity.

Table 1 shows that removal percentage of $\mathrm{Pb}(\mathrm{II})$ sorption reaches its maximal value when the metal ion concentration is $2.0 \times 10^{-3} \mathrm{~mol} \cdot \mathrm{l}^{-1}$. As we see at the range of concentration $0.2 \times 10^{-3}-1.0 \times 10^{-3} \mathrm{~mol} \cdot \mathrm{l}^{-1}$ full sorption of $\mathrm{Pb}(\mathrm{II})$ ions by investigated sorbent is observed. Therefore to determine sorption capacity volume of metal ion solution should be increased.

\subsection{Effect of Eluent}

Various acids- $\mathrm{HClO}_{4}, \mathrm{H}_{2} \mathrm{SO}_{4}, \mathrm{HCl}, \mathrm{HNO}_{3}$ were tested to select a suitable eluent. $\mathrm{HClO}_{4}$ shows the greatest influence on the desorption degree of lead ion (II). Various concentrations of $0.2-1.5 \mathrm{M} \mathrm{HCl}$ were tested to select a suitable tested eluent (Table 2).

In further experiments, $5 \mathrm{ml}$ of $0.5 \mathrm{M} \mathrm{HCl}$ was used as eluent. The adsorbent does not lose its sorption properties after regeneration and can be reused.

The optimal conditions of sorption (Table 3) were determined while studying sorption equilibrium of obtained new chelating sorbent with $\mathrm{Pb}^{2+}$ ions (exploring the influence of $\mathrm{pH}$ of solutions, ionic strength, $\mathrm{Pb}^{2+}$ ion concentration on the sorption, the dependence on time). 
It may be concerned with the arrangement and stability of remaining chelat cycles. Adsorption and desorption processes has been taken place in static condition.

\subsection{Using Method to Object}

Total 100 grams fresh samples of liver were collected from killed cattle’s in Baku. Samples were packed in sterile plastic bags, labeled with a marker, and stored frozen in freezer. Then frozen samples were transported to the research laboratory of the Baku State University for further processing and analysis. For the analysis took three liver samples, respectively $23.9387 \mathrm{~g}$ (I sample) $36.8022 \mathrm{~g}$ (II sample), $28.1416 \mathrm{~g}$ (III sample) of mass. To the first and the second samples $1 \mathrm{~g}$. $\mathrm{Pb}\left(\mathrm{CH}_{3} \mathrm{COO}\right)_{2}$ was added. Samples were dissolved in a graphite crucible under heating in $55 \mathrm{ml}$ of $\mathrm{HNO}_{3}$ (conc.). Within an hour, the liver was dissolved in acid. The solution was then calcined in the muffle furnace. Obtained weight of the ashes of the first sample is 4.6511, 5.1930-second sample, a third sample $-5.5223 \mathrm{~g}$. The resulting ash is dissolved in aqua regia. After the resulting mixture was dissolved in distilled water, the insoluble material was separated by filtration. The resulting solution was transferred into a flask of $100 \mathrm{ml}, \mathrm{pH}=6$ adjusted to the desired value, added to the mark with distilled water and mixed. In the prepared liver, lead $(\mathrm{Pb})$ residue was determined pre-concentration with chelating polymer. Then photometric determination of lead we used xylene orange as a reagent [17]. Data were presented on Table 4.

The concentration of lead in the liver samples ranged to $1.087 \mathrm{mg} / \mathrm{kg}$ with mean and standard deviation of $0.0067 \mathrm{mg} / \mathrm{kg}$.

Table 2. Effect of concentration and volume of eluent on recovery degree (R, \%) of determined $\mathrm{Pb}(\mathrm{II})$ ions $(\mathrm{n}=3)$.

\begin{tabular}{ccc}
\hline \multicolumn{2}{c}{ Concentration and volume of $\mathrm{HCl}$} & $\mathrm{Pb}(\mathrm{II}) \mathrm{R} \%$ \\
\hline $0.2 \mathrm{M}$ & $10 \mathrm{ml}$ & 90 \\
& $5 \mathrm{ml}$ & 86 \\
$0.5 \mathrm{M}$ & $10 \mathrm{ml}$ & 98 \\
& $5 \mathrm{ml}$ & 99 \\
$1.0 \mathrm{M}$ & $10 \mathrm{ml}$ & 96 \\
& $5 \mathrm{ml}$ & 100 \\
$2.0 \mathrm{M}$ & $10 \mathrm{ml}$ & 96 \\
& $5 \mathrm{ml}$ & 96 \\
\hline
\end{tabular}

Table 3. Optimal conditions of sorption ( ${ }^{*} \mathrm{~m}_{\text {sorp. }}=50 \mathrm{mg}$; $\left.\mathrm{V}_{\text {lic.ph. }}=20 \mathrm{ml}\right)$.

\begin{tabular}{cccccc}
\hline${ }^{* *}$ SC, mg/g & Sorption ratio, $\%$ & $\mathrm{pH}_{\mathrm{opt}}$ & ${ }^{* * *} \mu$, mol/l & Time, hour & D, mm \\
\hline 832 & 98 & 5 & 0.8 & 2.0 & 0.14 \\
\hline${ }^{*}$ Mass of sorbent; ${ }^{* *}$ Sorption capacity; ${ }^{* * *}$ Ionic strength of the adductor to a decrease in sorption.
\end{tabular}

Table 4. Results of the analysis (100 $\mathrm{ml}$ sample volume, the volume of eluent to $5 \mathrm{ml}$, $\left.\mathrm{m}_{\text {sorb }}=100 \mathrm{mg} ; \mathrm{P}=0.95 ; \mathrm{n}=5\right)$.

\begin{tabular}{cl}
\hline Samples of liver of cattle & Found, $\mathrm{Pb}(\mathrm{II}) \overline{\mathrm{X}} \pm \frac{\mathrm{t}_{\mathrm{p}} \mathrm{s}}{\sqrt{\mathrm{n}}, \times 10^{3} \mathrm{mg} / \mathrm{kg}}$ \\
\hline I & $1.087 \pm 0.0067$ \\
II & $1.085 \pm 0.0038$ \\
III & $0.118 \pm 0.0054$ \\
\hline
\end{tabular}




\section{Conclusion}

The present study has shown that maleic anhydride styrene copolymer based sorbents can be used for removal of $\mathrm{Pb}^{2+}$ ions from natural and industrial objects. Moreover, the functionally active groups of amine of 4-amino-2thiouracil show high selectivity over $\mathrm{Pb}^{2+}$ ions. The current method was successfully used for determination $\mathrm{Pb}^{2+}$ ions in the liver of murdered large cattle. Lead concentration was determined in liver samples of slaughtered cattle at Baku. There was a significant different in the concentration of lead in liver of the samples.

\section{References}

[1] Bala, A., Junaidu, A.U., Salihu, M.D., Onifade, K.I., Magaji, A.A., Faleke, O.O., Saulawa, M.A., Musawa, A.I., Mohammed, M, Muhammad, L.U., Pewan, S.B., Anzaku, S.A. and Emenna, P. (2012) Journal of Veterinary Advances, 2, 132.

[2] Blakley, B.R (1984) Veterinary and Human Toxicology. No. 26. 505.

[3] Bolter, E., Butz, T.R. and Arseneau, J.F. (1975) Iranian Journal of Veterinary Research. Toronto Canada, 10, 28.

[4] Bratton, G.R. and Zmudski, J. (1984) Veterinary and Human Toxicology. 26, 387.

[5] Wagner, H.P. (1995) Journal of America Society. Brewery Chemistry, 53, 141.

[6] Maxodoeva, O.B., Myasoedova, Q.V. and Kubrakova, I.V. (2007) JAX, B62, 454

[7] Losev, V.N, Barash, A.N., Volkova, Q.B., Baxvalova, I.P. and Jarova, L.A. (1999) Chemistry and Chemical Technology, P42, 41

[8] Arnautov, N.V. (1987) Standard Samples of the Chemical Composition of Natural Minerals: Method. Recommendations. IQiQSO ANASSSR, Novosibirsk, 204 p.

[9] Vasileva, I.E., Pojidaev, Y.N., Vlasova, N.N., Voronkov, M.Q. and Filipcenko, Y.A. (2010) Sorption-AtomicEmission Determination of Gold, Platinum and Palladium in Rocks and Ores Using Sorbent PSTM-3T. Analitical and Kontrol, P.14, 16.

[10] Wagner, H.P. (1995) Determination of Lead in Beer Using Zeeman Background Corrected Graphite Furnace Atomic Absorption Spectrometry. Journal of America Society. Brewery Chemistry, 53, 141-144.

[11] Akperov, O.N. and Akperov, E.O. (2002) Workshop on High-Molecular Chemistry. Baku, 231.

[12] Aliyeva, R.A., Hamidov, S.Z. and Chiragov, F.M. (2007) The Study of Sorption of Zn(II) Ions with Chemically Modified Synthetic Sorbent. Journal of Chemical Problems, No. 2, 28.

[13] Basargin, N.N. and Isayev, E.I. (1986) Correlation and Prediction of Analytic Properties of Organic Reagents and Chelating Sorbents. Nauka, Moscow, 199 p.

[14] Cepalev, S.V. (2011) Concentration of Metal Ions Polymer Complexing Sorbents in the Presence of Ligands Monodentantnyh: Extraction and Identification of Pb (II), Cd (II), Ni (II) in Natural Objects. Abstract of the Thesis for the Degree of Candidate of Chemical Sciences Moskva.

[15] Myasoedova, G.V. and Savvin, S.B. (1984) Chelating Sorbents. Nauka, Moscow, 173.

[16] Nazarenko, V.A., Antonovich, V.P. and Nevskaya, E.M. (1979) The Hydrolysis of Metal Ions in Dilute Solutions. M. Atomizdat, $192 \mathrm{p}$.

[17] Bulatov, M.I. and Kalinkin, I.P. (1972) Practical Book on Photometric and Spectrometric Methods of Analysis. L. Chemistry, $407 \mathrm{p}$. 


\section{Submit or recommend next manuscript to SCIRP and we will provide best service for you:}

Accepting pre-submission inquiries through Email, Facebook, LinkedIn, Twitter, etc.

A wide selection of journals (inclusive of 9 subjects, more than 200 journals)

Providing 24-hour high-quality service

User-friendly online submission system

Fair and swift peer-review system

Efficient typesetting and proofreading procedure

Display of the result of downloads and visits, as well as the number of cited articles

Maximum dissemination of your research work

Submit your manuscript at: http://papersubmission.scirp.org/ 